\title{
PROCEDURES FOR CARRYING OUT ACTIONS OF CONTROLLING PEST AND DISEASES OF VEGETABLES IN KARAKALPAKSTAN
}

\author{
Toreniyazov Elmurat Sherniyazovich \\ Doctor of Agricultural Sciences, Professor, \\ Nukus branch of Tashkent State Agrarian University, Nukus, Uzbekistan \\ Yusupov Risnazar Orazbaevich \\ Associate Professor, \\ Nukus branch of Tashkent State Agrarian University, Nukus, Uzbekistan
}

\author{
Durshimbetov Ispandiyar Kerimbergenovich \\ Associate Professor, \\ Nukus branch of Tashkent State Agrarian University, Nukus, Uzbekistan
}

Article DOI: https://doi.org/10.36713/epra6337

\begin{abstract}
The article provides information on the morphological characteristics of pests and diseases of melons in the Republic of Karakalpakstan, the characteristics of bioecological development, the degree of damage, control measures. The biological effectiveness of chemical measures against pests and diseases is presented.

KEYWORDS: melons, pests, diseases, control, biological effectiveness.
\end{abstract}

\section{INTRODUCTION}

One of the most popular agricultural crops which are being sown in Karakalpakstan, as in many other regions, is vegetables and they differ with their fastripeness, tasteless, being rich in nutrients and usefulness. According to the suggestion of medical researches, using an average of $19,5 \mathrm{~kg}$ of vegetables for each person per year is the most necessary method for health. Today, different kinds of vegetables are being sown to 6,000 hectares of arable land of farms and agricultural fields. The average of total product which is received from the field is 100,611 tons. This means that the role of vegetable products in providing the population with such food products during the year is special.

In the conditions of the Republic of Karakalpakstan, there are a lot of problems in the cultivation of vegetable crops, and the degree of damage caused by pests and diseases during the vegetation period dramatically decreases the amount and quality of the product. Therefore, today's actual problem is to carry out scientific research works on studying common types, morphological features, peculiarities of bio ecological development, spreading areas, the degree of damage of pests and diseases of vegetables and the biological effectiveness of actions on controlling them.

\section{MATERIALS AND METHODS}

Our research work was carried out in 2018-2020 in the Kegeyli, Chimbay, Nukus districts of the Republic of Karakalpakstan on the vegetable sowing farms and agricultural fields. The methods of V.B. Golub, Sh.T. Khojaev, V.I. Tanskiy., K.K. Fasulati., V.F. Paliy were used for researching morphological signs, bioecology of vegetable pests and actions of controlling them, V.I. Bilay, P.N. Golovin, M.A. Litvinov, T.A. Dobrazrakova and others methods for identifying diseases and A.E. Chumakov, T.I. Zakharova's methods to determine the spreading level of diseases.

The biological efficacy of the used preparations (drugs) was determined by using the V.Abbot's formula [10]. Mathematical and statistical calculations of both experiments and results were performed using the method of B.A. Dospekhov [8]. 


\section{SJIF Impact Factor 2021: 7.13| ISI I.F.Value:1.241| Journal DOI: 10.36713/epra2016 \\ ISSN: 2455-7838(Online) \\ EPRA International Journal of Research and Development (IJRD) \\ Volume: 6 | Issue: 2 | February 2021 \\ - Peer Reviewed Journal}

\section{RESULTS AND DISCUSSION}

As a result of the scientific research work on the study of pests and diseases of vegetables and organizing actions of controlling them in the condition of the Republic of Karakalpakstan, it was defined that in the fields of melon, watermelon, and pumpkin, which are the main types of vegetables, the following kinds of pests damage mostly: melon fly (Myiopardalis pardalina Big.), leafminer fly Liriomyza bryoniae (Kaltenbach), aphids - Aphididae, turnip moth - Agrotis segetum Den. Et Schif., Click beetle - Agrotes meticulosus Cond. Melon fly, which is the main object of the research, has been determined in the fields of vegetables since 2001 [9]. Since this year, research has been conducted on the origin, distribution, morphological structure, peculiarities of bioecological development, degree of damage, organizing control.

Melon fly is considered to be an oligophagous species due to its variability in feeding. In Pakistan, Turkey, Israel, Iran, the Caucasus, Georgia, Armenia, Azerbaijan, Russia, Afghanistan, Tajikistan, and Turkmenistan, adults of the pest have been found to be highly harmful to the fruits of vegetables $[2,3,5,14$, $18,20,21,22,24,27]$.

It is known that in the conditions of our Republic, as a result of damage caused by melon fly $90-100 \%$ of the yields were damage at the beginning when they appeared.

During our experiments, the morphological features of melon fly were determined by increasing the number of adults in the field and in the laboratory. It turned out that the average body size of the pest analyze was $6,0-7,0 \mathrm{~mm}$, the paternity was $5,5-6,0 \mathrm{~mm}$, and the length of the egg was around $0,35-1,0 \mathrm{~mm}$. The egg is elongated, with a white, shiny color, and the analyze lays eggs under the fruit cover with the help of special growing part. The larva of the pest are on average 9,0 $10,0 \mathrm{~mm}$ long, white, the legs are almost undeveloped. In most cases, the worms pierce the fruit cortex in the morning or in the evening. This is because the sunlight does not fall vertically during this time, which prevents the worms from crawling or freezing. The next phase is the period of pupa, which takes place underground. The pupae are reddish-brown or yellowish-red, about $7 \mathrm{~mm}$ long, and in this phase they pass into the adult phase. This means that, as it turns out, the pests are included in the polyvoltine-developing animals, with a total of three or four offspring during the vegetation period.

It has been found that melon fly is more harmful to melon varieties than to types of watermelon. It was defined that the following types of melon: $98-100 \%$ of Gurbek, $50-60 \%$ of yellow Gulaby, $40-55 \%$ of Bishek, and the following types of watermelon: $60-70 \%$ of farmer kind, $60-65 \%$ of agricultural kind were damaged.

In the conditions of the republic, according to the bio ecological diversity of the pest in the multi-year observations the pest appears in melon fields in the first ten days of June. Wintering lasts until the end of June, depending on soil conditions. The first offspring go through the full developmental phase, and the second offspring are mixed with the first offspring. This situation will be repeated in future generations. This means that it is necessary to take into account above mentioned actions in the treatment of each phase of the pest.

A number of chemicals have been tested against the adult phase in the treatment of melon fly pests. The results are given in Table 1 , and in the first variant biological effectiveness $98,1 \%$ on the 14 th day when the drug containing deltamethrin was used 0,7 liters per hectare, in the second variant it was $97,1 \%$ on the 14thday when the drug containing lambda-cyhalothrin was used 0,5 liters per hectare, in the third variant it was $97,0 \%$ when the drug with cypermethrin + chlorpyrifos was used in the amount of 0,7 liters, in the fourth variant it was $92,9 \%$ on the 14 th day when the drug containing abamectin was used 0,6 liters per hectare, in the next variant it was $83,3 \%$ when the drug with malathion was used.

As can be seen from our experiments, high biological efficiency has been achieved in the variant in which the drug deltamethrin is used.

Table 1

Biological efficiency of insecticides against adults of melon fly pests

(Chimbay district, KKSSRI, field experience, 2018-2020)

\begin{tabular}{|c|c|c|c|c|c|c|c|c|}
\hline \multirow[t]{2}{*}{ № } & \multirow{2}{*}{ Containing element } & \multirow{2}{*}{$\begin{array}{l}\text { Norm of the } \\
\text { drug, l/ha or } \\
\mathrm{kg} / \mathrm{ha}\end{array}$} & \multirow{2}{*}{$\begin{array}{l}\text { Average number } \\
\text { of the pest in } 10 \\
\text { plants before } \\
\text { using chemicals }\end{array}$} & \multicolumn{5}{|c|}{ Biological effectiveness, $\%$ in days } \\
\hline & & & & $\mathbf{1}$ & 3 & 7 & 14 & 21 \\
\hline 1 & Deltamethrin & 0,7 & 2,7 & 84,3 & 90,7 & 97,6 & 98,1 & 83,7 \\
\hline 2 & Lambda-cyhalothrin & 0,5 & 2,7 & 82,5 & 88,7 & 96,4 & 97,1 & 82,5 \\
\hline 3 & Cypermethrin + chlorpyrifos & 0,7 & 2,5 & 81,8 & 81,9 & 95,9 & 97,0 & 81,7 \\
\hline 4 & Abamectin & 0,6 & 2,3 & 80,4 & 80,2 & 90,1 & 92,9 & 80,1 \\
\hline 5 & Malathion & 1,0 & 2,5 & 77,6 & 79,2 & 82,3 & 83,8 & 70,2 \\
\hline \multirow[t]{2}{*}{6} & Control (without using chemicals) & - & 2,7 & - & - & - & - & - \\
\hline & $\mathrm{LSD}_{05}$ & & & 0,51 & 0,44 & 0,54 & 0,44 & 0,52 \\
\hline
\end{tabular}




\section{SJIF Impact Factor 2021: 7.13| ISI I.F.Value:1.241| Journal DOI: 10.36713/epra2016 \\ ISSN: 2455-7838(Online) \\ EPRA International Journal of Research and Development (IJRD) \\ Volume: 6 | Issue: 2 | February 2021 \\ - Peer Reviewed Journal}

It was obvious that total thirty seven types of fungal pathogens, which cause disease in the seeds, were found in melon fields where the research was carried out. Of these, Gliocladium roseum - 13,6\%, Alternaria humicola - 12,3\%, Penicillium expansum and Verticillium dahliae - 10,0\%, and Fusarium solani $2,0 \%$ were found to be damaged in seeds.

In addition, ten types of the mushrooms that caused the disease in the leaves and stems of the melon were found, and 100 strains were isolated from them. During the observations it was found that 51,2 percent of the plant was damaged by this disease, the largest number of which were detected in fusarium wilt, powdery mildew, and alternariosis.
Biological effectiveness of using fungicides Previkur SL 722 (1,5 kg/ha) and Falcon (0,4 1/ha) and Alto Super (0,3 1/ha) after 15 days, 30 days and 45 days was studied during the experiments. As can be seen from Table 2, biological effectiveness was 91,2; 83,1; $79,6 \%$ during these days when the Previkur SL 722 (1,5 $\mathrm{kg} / \mathrm{ha}$ ) fungicide was used, 86,$3 ; 78,4 ; 72,1 \%$ when Falcon $46 \%$ EC $(0,41 /$ ha) was used, 80,$3 ; 72,2 ; 65,3 \%$ when Alto Super, $33 \%$ EC (0,3 1/ ha) was used.

It is obvious from the research work that the use of special fungicides is required from the time when symptoms of disease appear in plant. Previkur (1,5 $\mathrm{kg} / \mathrm{ha}$ ) of the three fungicides was highly biologically effective when it was used to control the disease.

Table 2

Biological efficiency used chemical fungicides against of melon diseases

(Republic of Karakalpakstan, Kegeyli district, "Aynazar Baba” farm, experience of production, 2018-2019)

\begin{tabular}{|c|c|c|c|c|}
\hline \multirow{2}{*}{$\begin{array}{c}\text { Experimenting variants, } \\
\text { norms }\end{array}$} & \multirow{2}{*}{$\begin{array}{l}\text { Fungicide } \\
\text { rate, kg/ha } \\
\text { or l/ha }\end{array}$} & \multicolumn{3}{|c|}{ Biological effectiveness after how many days: } \\
\hline & & 15 & 30 & 45 \\
\hline Previkur SL 722 WSC & 1,5 & 91,2 & 83,1 & 79,6 \\
\hline Falcon $46 \%$, EC & 0,4 & 86,3 & 78,4 & 72,1 \\
\hline Alto Super 33\%, EC & 3 & 80,3 & 72,2 & 65,3 \\
\hline
\end{tabular}

\section{CONCLUSION}

The analysis of the results of the experiments showed that the melon fly gives 3-4 offspring in the regional conditions, which causes a high degree of damage to mainly early and medium ripening varieties of melon. Diseases such as lying powdery mildew, powdery mildew, mountain sickness, salivary diseases, vascular diseases were found and high biological efficiency is achieved when controlling actions were carried out on time.

It is possible to decrease the number of pests to the level, which does not bring to economic damage, by using the recommended drug to adults of the melon fly from 5 to 8 o'clock in the morning through pouring it with the help of OBX-28 aggregate in large fields and in small fields with the help of hand pouring things.

High biological efficiency was achieved in the variant when Previkur SL 722, WSC was used in the amount of $1,5 \mathrm{~kg}$ per hectare to control diseases. This means that yield is saved by organizing actions of controlling pests and diseases on time and as the shown amount during the growing and developing period of melon.

\section{REFERENCES}

1. Allayarov A.N., Abdurakhmonova S.B., Khakimov A.A. The spread of alternaria leaf spot disease in cabbage vegetable plants, its damages and the efficacy of fungicides used against them. EPRA International Journal of Research and Development (IJRD), 2019, Volume 4, Issue 2, pp. 118-122

2. Baris A., Cobanog 'lu S. Kavun Sinegi [Myiopardalis pardalina (Bigot, 1891) (Diptera: Tephritidae)] nin
Farkli Kavun Cesitlerin deki Zarar Oranlarinin Belirlenmesi/Proceedings of the fourth plant protection congress of Turkey. - Kahramanmaras, 2011. 14 p.

3. Barry S., Zaheer H., Gul A. Control of melon fly (Bactrocera cucurbitae, Diptera: Tephritidae) with insecticidal baits, in Afghanistan. International Pest Control. 2002. pp. 304-306.

4. Bilay V.I. Biological active substances of microscopic fungi. - Kiev, 1985.

5. Chughtai G.H., Khan L. Studies on the biology and chemical control of melon fly, Myiopardalis pardalina Bigot. Pakistan entomologist. Vol. 1-2, 1983. pp. 17-20.

6. Chumakov A.E., Zakharova T.I. Harmful to diseases of agricultural crops. Moscow, Agroprom Publishing House, 1990. $126 \mathrm{p}$.

7. Dobrozrakova T.A., Letova M.F., Stepanov K.M., Khokhryakov M.K. Identifier of plant diseases. Moscow Leningrad: Selkhozgiz, 1956. 430 p.

8. Dospekhov B.D. Field Experiment Technique $\left(4^{\text {th }}\right.$ edition). Moscow: "Kolos", 1986. 351 p.

9. Fasulati K.K. Ecology and economic importance of insects. Leningrad, 1961. $231 \mathrm{p}$.

10. Gar K.A. Test methods for toxicity and effectiveness of insecticides. - Moscow: "Agricultural literature, magazines and posters", 1963. $167 \mathrm{p}$.

11. Golovin P.N. Powdery fungi parasitizing cultivated plants. -M. -L.: - Ed. ANSSSR, 1960. 267 p.

12. Golub V.B., Kolesova D.A., Shurovenkov Yu.B. Entomological and phytopathological collections, their compilation and storage. - Voronezh: "VU Publishing House", 1980. 228 p.

13. Identifier of agricultural pests for damage to cultivated plants (Ed. By G.E. Osmolovsky). Leningrad: "Kolos", 1976. 
14. Kandybina M.N. Larva of fruit flies of the genus Carpomyia A Costa (Diptera, Trypetidae). Entomological Review. T 45. Issue 3. 1965. pp. 665-672.

15. Khakimov A.A., Omonlikov A.U., Utaganov S.B. Current status and prospects of the use of biofungicides against plant diseases. GSC Biological and Pharmaceutical Sciences. Vol. 13, Issue 3, 2020, pp. 119-126. https://doi.org/10.30574/gscbps.2020.13.3.0403

16. Litvinov M.A. Keys to microscopic soil fungi. Leningrad, 1967. $174 p$.

17. Mamiev M.S., Khakimov A.A., Zuparov M.A., Rakhmonov U.N. Effectiveness of different fungicides in controlling botrytis grey mould of tomato. 1st International Conference on Energetics, Civil and Agricultural Engineering 2020" (ICECAE 2020), 14-16 October 2020, Tashkent, Vol. 614, 012112, doi:10.1088/17551315/614/1/012112

18. Mikhailov K.G. Melon fly. J. Plant protection. - Moscow, 1963. №.2. pp. 26-27.

19. Paly V.F. Methods of studying the fauna and phenology of insects. Voronezh, 1970. $189 \mathrm{p}$.

20. Rekach V.N. Materials on biology and control of melon fly Carpomyia (myiopardalis) caucasicazaitz. Proceedings of the Azerbaijan Central Agricultural Experimental and Breeding Station named after Sergo Ordzhonikidze. Issue 9. Edition of the NKZ ASSR. Baku, 1930. $27 p$.

21. Saparmamedova N.K. To the study of the melon fly Myiopardalina Big in Turkmenistan. Entomological Review. LXXXIII. 2004. No. 3. pp. 517-519.

22. Shavkatsishvili L. D. Melon fly. Pests and diseases of vegetable crops. Moscow, 1955. pp. 342-343.

23. Tansky V.I. The harmfulness of insects and methods of its study. Moscow: VNIITEISH, 1975. 68 p.

24. Tolikhov D.A. Features of growing melons in Tajikistan, yield and quality of fruits in irrigated conditions: Abstract of dissertation candidate of agricultural sciences. Dushanbe, 2016. pp. 3-16.

25. Toreniyazov E.Sh. Melon fly on melon crops. J. Plant Protection and Quarantine. Moscow, 2006. №.6. pp. 5152.

26. Khodjaev Sh.T. Guidelines for testing insecticides, acaricides, biologically active substances and fungicides (II edition). - Tashkent, 2004. 102 p.

27. Zaitsev F.A. Transcaucasian melon fly, Corpomyia (Myiopardalis) caucasicasp.n. Zap. Tifl. Bot. Garden, 1919. No. 1. pp. 24-27.

28. Zuparov M.A., Khakimov A.A., Mamiev M.S., Allayarov A.N. In vitro efficacy testing of fungicides on Botrytis cinerea causing gray mold of tomato. International Journal on Emerging Technologies, 2020, 11(5), pp. 5055 . 